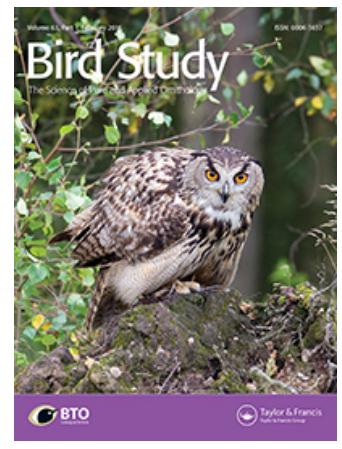

Bird Study

\title{
Brood-guarding behaviour in Bulwer's Petrel (Bulweria bulwerii) at two East Atlantic colonies
}

\section{Maria Pinto, Teresa Catry, Patrícia I. Pedro, Marie Claire Gatt \& Maria P. Dias}

To cite this article: Maria Pinto, Teresa Catry, Patrícia I. Pedro, Marie Claire Gatt \& Maria P. Dias (2016) Brood-guarding behaviour in Bulwer's Petrel (Bulweria bulwerii) at two East Atlantic colonies, Bird Study, 63:1, 148-151, DOI: 10.1080/00063657.2015.1136262

To link to this article: http://dx.doi.org/10.1080/00063657.2015.1136262

\section{曲 Published online: 24 Feb 2016.}

Submit your article to this journal $\pi$

LII Article views: 50

Q View related articles $\longleftarrow$

View Crossmark data $\nearrow$ 


\title{
Brood-guarding behaviour in Bulwer's Petrel (Bulweria bulwerii) at two East Atlantic colonies
}

\author{
MARIA PINTO ${ }^{1,2 *}$, TERESA CATRY ${ }^{3}$, PATRÍCIA I. PEDRO ${ }^{3}$, MARIE CLAIRE GATT $^{5}$ and MARIA P. DIAS ${ }^{4,6}$ \\ ${ }^{7}$ Faculdade de Ciências da Universidade de Lisboa, Campo Grande 1749-016, Lisboa, Portugal; ${ }^{2}$ Department of \\ Limnology \& Bio-Oceanography, University of Vienna, Althanstrasse 14, Vienna 1090, Austria; ${ }^{3}$ Centro de Estudos \\ do Ambiente e do Mar (CESAM), Departamento de Biologia Animal, Faculdade de Ciências da Universidade de \\ Lisboa, Campo Grande, Lisboa 1749-016; ${ }^{4}$ MARE - Marine and Environmental Sciences Centre, ISPA - Instituto \\ Universitário, Rua Jardim do Tabaco 34, $1149-041$ Lisboa, Portugal; ${ }^{5}$ School of Science and the Environment, \\ Manchester Metropolitan University, Manchester, UK; ${ }^{6}$ BirdLife International, Wellbrook Court, Girton Road, \\ Cambridge CB3 ONA, UK
}

Capsule We characterized the brood-guarding behaviour of the Bulwer's Petrel Bulweria bulwerii at two Atlantic colonies. Our results suggest that predation avoidance might be a major factor driving broodguarding duration on this species.

During the days after hatching, most seabird chicks are continuously attended by at least one of the parents, a behaviour that is generally referred to as broodguarding (Catry et al. 2010). The duration of the brood-guarding period is highly variable between species (Ricklefs \& Roby 1983, Varpe et al. 2004), ranging from less than a week in small petrels (Boersma et al. 1980) to more than three weeks in some albatrosses Diomedeidae (Catry et al. 2010). Brood-guarding allows for the reduction in the thermoregulatory energy costs of the newly hatched heterothermic chick (Klaassen 1994). However, in many colonial bird species, chicks are brood-guarded for longer than the time needed to reach homeothermy (Catry et al. 2009), suggesting that brood-guarding is important in other ecological functions related with chick condition and survival. Small petrels often breed in sympatry with predators such as skuas, gulls, raptors and crows, which can take both adult and young petrels as prey (Oro et al. 2005, Matias \& Catry 2010).

The lunar cycle might also play an indirect role in regulating brood-guarding duration, by influencing the colony attendance patterns (Mougeot \& Bretagnolle 2000). Most small petrels avoid attending the colony during moonlit nights, when many predators

*Correspondence author. Email: maria.pinto@univie.ac.at experience higher success rates (Nelson 1989, Oro et al. 2005, Watanuki 1986).

In this study, we analysed the brood-guarding behaviour of the Bulwer's Petrel Bulweria bulwerii breeding on the two most important colonies for this species in the Atlantic, located in the Madeira archipelago (Macaronesia; BirdLife International 2015). The Bulwer's petrel is the most nocturnal of all seabird species studied so far (Dias et al. 2015); therefore, we also evaluated the possible effect of the lunar cycle on brood-guarding duration and chick development.

Field work was conducted on Selvagem Grande Island $\left(30^{\circ} 09^{\prime} \mathrm{N}, 15^{\circ} 52^{\prime} \mathrm{W}\right)$ and on Deserta Grande Island $\left(33^{\circ}\right.$ $\left.20^{\prime} \mathrm{N}, 17^{\circ} 20^{\prime} \mathrm{W}\right)$, Madeira archipelago, Portugal, in 2012 and 2014, respectively. Eighty-eight nests were marked in each study site during incubation (early June). Nests were checked daily in the same order during the morning (when no adult arrivals or departures were recorded) until the end of the breeding season (midSeptember) on Selvagem and until mid-August (with additional visits on the 19th and 30th August and on the 5th of September, to assess fledging success) on Deserta. Diurnal nest attendance by the parents was recorded in both colonies. On Selvagem, chicks were weighed daily (to the nearest $\mathrm{g}$ ), and wing length was measured (to the nearest $\mathrm{mm}$ ) every three days. On Deserta, the chicks were weighed only when they were 
10 days old. A record of chicks found dead or missing from their nest was kept in both colonies, with a note of the possible cause.

We defined brood-guarding duration (hereafter Brood) as the total number of days in which chicks were found attended by one of the parents in the first 10 days after hatching; Mass 10 as the mass of the chicks at 10 days of age; Mass 30 as the mass at 30 days of age (the point at which the exponential chick growth ceases; Nunes \& Vicente 1998) and Wing11 as the wing length at 11 days of age.

Spearman's rank correlations were used to test for a correlation between Brood and hatching date in each colony. We used linear models to analyse the influence of Brood on Mass10, Mass30, mass at fledging and Wing11. The two colonies were analysed separately, since environmental factors such as weather conditions and food availability are known to influence chick early development and may vary between colonies and years (Konarzewski \& Taylor 1989, Kitaysky et al. 2000). Linear mixed models were also used to test for the influence of moonlight at hatching date (measured as the percentage of visible moon disk at midnight http:// aa.usno.navy.mil/data/docs/MoonFraction.php) on Brood and Mass10. Generalized linear models (binomial family, with logit link) were used to test for the effect of Brood on chick survival and fledging success (both binomial response variables), and of hatching date on fledging success. All statistical analyses were performed with the statistical software R (R Development Core Team 2012), considering a level of significance of 0.05 . Means \pm SD are presented, except if otherwise stated. Sample sizes may differ depending on the tests, due to chick mortality in the first days of age.

Hatching success of Bulwer's Petrel was $65 \%(n=88)$ on Selvagem and 64\% $(n=88)$ on Deserta. The hatching period lasted for 17 days on both colonies (10-26 of July on Selvagem and 13-29 of July on Deserta).

A total of 19 of the studied chicks died on Selvagem and 14 on Deserta, resulting on a final fledging success of $67 \% \quad(n=57)$ and $71 \% \quad(n=56)$, respectively. Chicks found missing from the nests (11 in Selvagem and 10 in Deserta) were considered to have been predated (most likely by Atlantic Yellow-legged Gulls Larus michahellis atlantis, which are often seen predating Bulwer's Petrel chicks in these colonies; personal observations; Matias \& Catry 2010). One chick in Selvagem was found being predated by Madeiran Wall Lizards Teira dugesii. Chick survival at 10 days of age and fledging success did not differ significantly between the two colonies (Fisher's exact test: $P=0.074$ and $P=0.54$, respectively).

Brood varied from 0 to 6 days and was significantly higher on Selvagem (2.16 \pm 1.24 ; range $1-6$ days; $n=$ 55) than on Deserta $(1.67 \pm 1.00$; range $0-4$ days; $n=$ 52; $t$-test: $t=6.05, P<0.001)$. Mass10 was similar in chicks from Selvagem $(45.16 \pm 10.16 \mathrm{~g}, n=44)$ and Deserta $(43.57 \pm 10.01 \mathrm{~g}, \quad n=51 ; t=0.74, P=0.46)$. We found a significantly lower Mass10 for chicks brooded for longer in Selvagem, while no relationship was found between Mass10 and brood-guarding duration on Deserta (Table 1) We did not find any other influence of Brood on the condition or survival of chicks, either on Selvagem or Deserta (Table 1). Chicks hatching earlier in the season were broodguarded for longer than late-hatched chicks on Selvagem, but not on Deserta (Spearman's rank correlation test: $r=-0.30, P=0.042, n=45$ and $r=$ $0.14, P=0.340, n=51$, respectively; Fig. 1). Fledging success was not affected by hatching date (Selvagem, $Z=-0.048, P=0.96, n=57 ;$ Deserta, $Z=0.57, P=$ $0.57, n=57)$. Brood was negatively influenced by moonlight at hatching date $(t=-2.24, P=0.028, n=$ 96), while Mass 10 was not significantly influenced by the moonlight $(t=1.19, P=0.24, n=96)$.

Our results showed that longer brood-guarding periods in Bulwer's Petrel did not positively affect chick survival or growth. In fact, the opposite pattern was found on Selvagem (i.e. brood duration negatively correlated with chick mass at age 10), suggesting that there are factors, other than the body condition of the chicks, driving this behaviour.

We also found a negative relationship between hatching date and brood-guarding duration in Selvagem. A seasonal decline in brood-guarding duration has been shown in other seabird species such as albatrosses (Catry et al. 2010), and is often related with predation risk (the synchronization hypothesis; Catry et al. 2009) given that, by synchronizing the end of brooding, the individual probability of a chick being predated decreases due to a dilution effect (Ims 1990; Catry et al. 2009).

The population size of Bulwer's Petrels on Deserta (approximately 45000 pairs; Catry et al. 2015) is several times higher than on Selvagem (approximately 5000 pairs; Ramírez et al. 2008), so the individual predation risk on Selvagem is probably much higher than on Deserta, which could explain the seasonal trend in brood-guarding duration only being obvious in the former, and the longer brood-guarding duration on Selvagem. Both adults and chicks of Bulwer's Petrels 
Table 1. Influence of brood-guarding duration (Brood) on chick growth, development and survival. Mass $10=$ mass of chicks at their 10 th day of age, Mass $30=$ mass of chicks at their 30th day of age, Wing $11=$ wing length of the chicks on their 11 th day of age. GLM = general linear model. Chicks from Deserta were not monitored until fledging, therefore no results are presented for the influence of Brood on Mass30, Mass at fledging and Wing 11 in Desereta.

\begin{tabular}{|c|c|c|c|c|}
\hline & \multicolumn{2}{|c|}{ Selvagem } & \multicolumn{2}{|c|}{ Deserta } \\
\hline & Statistics & $P$-value & Statistics & $P$-value \\
\hline Mass 10 & $\begin{array}{l}\text { Linear model: } \\
t_{44}=-0.35\end{array}$ & $=0.021$ & $\begin{array}{l}\text { Linear model: } \\
t_{51}=0.34\end{array}$ & $=0.73$ \\
\hline Mass30 & $\begin{array}{l}\text { Linear model: } \\
t_{43}=0.33\end{array}$ & $=0.75$ & - & - \\
\hline Mass at fledging & $\begin{array}{l}\text { Linear model: } \\
t_{38}=-0.93\end{array}$ & $=0.36$ & - & - \\
\hline Wing 11 & $\begin{array}{l}\text { Linear model: } \\
t_{43}=-1.0\end{array}$ & $=0.31$ & - & - \\
\hline Chick survival at 10 days of age & $\begin{array}{l}\text { GLM (binomial): } \\
Z=0.78, n=45\end{array}$ & $=0.11$ & $\begin{array}{c}\text { GLM (binomial): } \\
Z=-0.52, n=51\end{array}$ & $=0.60$ \\
\hline Fledging success & $\begin{array}{l}\text { GLM (binomial): } \\
Z=0.91, n=45\end{array}$ & $=0.36$ & $\begin{array}{l}\text { GLM (binomial): } \\
Z=-1.04, n=51\end{array}$ & $=0.30$ \\
\hline
\end{tabular}

(a)
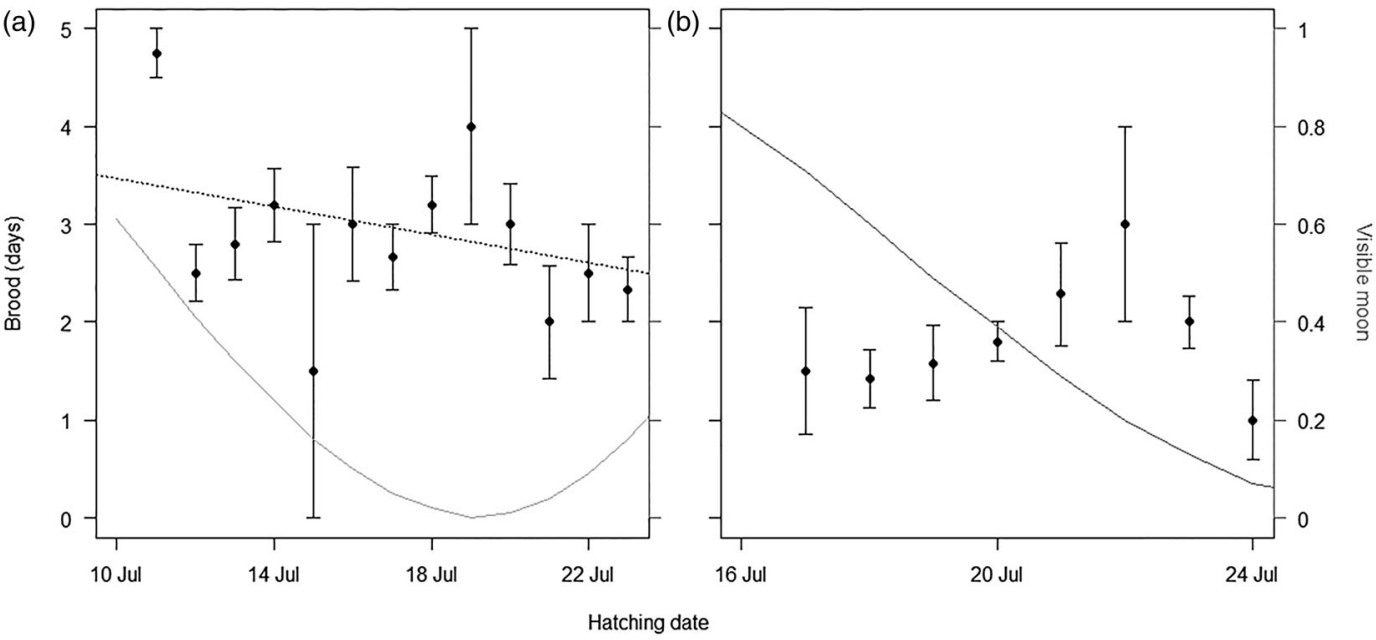

Figure 1. Relationship between hatching date and brood-guarding duration (Brood, average \pm SD days) in Bulwer's Petrel breeding on (a) Selvagem $(n=45)$ and (b) Deserta $(n=51)$. Dashed line in panel (a) represents the significant correlation found for Selvagem colony (Linear model: $\left.t_{44}=-0.35, P=0.021\right)$. Grey lines represent the proportion of visible moon, which had a significant influence on Brood (Linear mixed model: $t=-2.24, P=0.028, n=96)$.

are a common prey species of Atlantic Yellow-legged Gulls on Selvagem (Matias \& Catry 2010) and on Deserta (pers. obs.; Lourenço Alves pers. obs.). Other predators of very young chicks from Selvagem and Deserta are the highly abundant Madeiran Wall Lizards (Matias et al. 2009).

The lunar cycle had a significant effect on the broodguarding duration of Bulwer's Petrel in the two studied colonies, with chicks hatched around full moon being brood-guarded for shorter periods. The lunar cycle is known to impact colony attendance in small nocturnal
Procellariiformes (Mougeot \& Bretagnolle 2000). In general, birds attend the colony more often on dark, new-moon nights, which is usually explained as an anti-predator behaviour (Rubolini et al. 2014). The lunar cycle may also affect the foraging success of Bulwer's Petrels by influencing the sub-surface availability of mesopelagic fishes and squids (Hernandez-Leon et al. 2002), which represent the bulk of their diet (Neves et al. 2011). However, we did not find any relationship between Mass10 and moonlight, suggesting that it is predation risk, rather 
than foraging efficiency, driving the observed relationship between brood-guarding and the moon phase. This conclusion is also supported by the recent evidence that the lunar cycle has no significant effect on the nocturnal at-sea flying activity of this highly nocturnal seabird (Dias et al. 2015). The influence of the moon on brood-guard duration was evident under different lunar patterns and by pooling the data from the two studied colonies (hatching peak occurred during full moon in Selvagem in 2012 and during the last quarter in Deserta in 2014), revealing that this factor should be further considered in studies aiming to characterize the brood-guarding behaviour of other similar species.

\section{ACKNOWLEDGEMENTS}

We are extremely grateful to Serviço do Parque Natural da Madeira for the permits to conduct field work and for all assistance provided. We thank also Silke Waap, João Moura and Pedro Lourenço for helping in data collection in 2012 and finally to José Pedro Granadeiro and Paulo Catry for the revision to the first drafts of the manuscript.

\section{FUNDING}

This study was funded by Fundação para a Ciência e a Tecnologia (FCT, Portugal), POPH/QREN/FSE and European Regional Development Fund, through projects PTDC/MAR/121071/2010, PEst-OE/MAR/UI0331/2011 and a postdoctoral grant to TC [SFRH/BPD/102255/2014].

\section{REFERENCES}

BirdLife International. 2015. Species factsheet: Bulweria bulwerii. Downloaded April 18, 2015, from http://www.birdlife.org.

Boersma, P.D., Wheelwright, N.T., Nerini, M.K. \& Wheelwright, E. S. 1980. The breeding biology of the Fork-tailed Storm-Petrel (Oceanodroma furcata). Auk 97: 268-282.

Catry, P., Dias, M.P., Catry, T., Pedro, P., Tenreiro, P. \& Menezes, D. 2015. Bulwer's petrels breeding numbers on the Desertas Islands (Madeira): improved estimates indicate the NE Atlantic population to be much larger than previously thought. Airo 23: 10-14.

Catry, P., Matias, R., Vicente, L. \& Granadeiro, J.P. 2009. Broodguarding behaviour in Cory's shearwaters Calonectris diomedea. J. Ornithol. 150: 103-108.

Catry, P., Phillips, R.A., Forster, I.P., Matias, R., Lecoq, M., Granadeiro, J.P. \& Strange, I.J. 2010. Brood-guarding duration in black-browed albatrosses Thalassarche melanophris: temporal, geographical and individual variation. J. Avian Biol. 41: 460-469.
Dias, M.P., Alho, M., Granadeiro, J.P. \& Catry, P. 2015. Wanderer of the deepest seas: migratory behaviour and distribution of the highly pelagic Bulwer's petrel. J. Ornithol. 156: 955-962.

Hernandez-Leon, S., Almeida, C., Yebra, L. \& Aristegui, J. 2002. Lunar cycle of zooplankton biomass in subtropical waters: biogeochemical implications. J. Plankton Res. 24: 935-939.

Ims, R.A. 1990. On the adaptive value of reproductive synchrony as a predator-swamping strategy. Am. Nat. 136: 485-498.

Kitaysky, A.S., Hunt Jr, G.L., Flint, E.N., Rubega, M.A. \& Decker, M. B. 2000 . Resource allocation in breeding seabirds: responses to fluctuations in their food supply. Mar. Eco.I Prog. Ser. 206: 283-296.

Klaassen, M. 1994. Growth and energetics of tern chicks from temperate and polar environments. Auk 111 : 525-544.

Konarzewski, M. \& Taylor, J.R. 1989. The influence of weather conditions on growth of Little Auk Alle alle chicks. Ornis Scand. 20: 112-116.

Matias, R. \& Catry, P. 2010. The diet of Atlantic Yellow-legged Gulls (Larus michahellis atlantis) at an oceanic seabird colony: estimating predatory impact upon breeding petrels. Eur. J. Wildlife Res. 56: 861-869.

Matias, R., Rebelo, R., Granadeiro, J.P. \& Catry, P. 2009. Predation by Madeiran wall lizards Teira dugesii on Cory's shearwater Calonectris diomedea hatchlings at Selvagem Grande, North Atlantic. Waterbirds 32: 600-603.

Mougeot, F. \& Bretagnolle, V. 2000. Predation risk and moonlight avoidance in nocturnal seabirds. J. Avian Biol. 31: 376-386.

Nelson, D.A. 1989. Gull predation on Cassin's Auklet varies with the lunar cycle. Auk 106: 495-497.

Neves, V.C., Nolf, D. \& Clarke, M.R. 2011. Diet of Bulwer's Petrel (Bulweria bulwerii) in the Azores, NE Atlantic. Waterbirds 34: 357362.

Nunes, M. \& Vicente, L. 1998. Breeding cycle and nestling growth of Bulwer's Petrel on the Desertas Islands, Portugal. Colon. Waterbirds 21: 198-204.

Oro, D., de León, A., Minguez, E. \& Furness, R.W. 2005. Estimating predation on breeding European Storm-Petrels (Hydrobates pelagicus) by Yellow-legged Gulls (Larus michahellis). J. Zool. 265: 421-429.

Ramírez, I., Geraldes, P., Meirinho, A., Amorim, P. \& Paiva, V. 2008. Áreas Marinhas Importantes para as Aves em Potugal. Sociedade Portuguesa Para o Estudos das Aves, Lisboa.

R Development Core Team. 2012. R: A Language and Environment for Statistical Computing. R Foundation for Statistical Computing, Vienna. ISBN 3-900051-07. http://www.R-project.org/.

Ricklefs, R.E. \& Roby, D.D. 1983. Development of homeothermy in the diving petrels Pelecanoides urinatrix exsul and P. georgicus, and the Antarctic Prion Pachyptila desolata. Comp. Biochem. Phy. A. 75: 307-311.

Rubolini, D., Maggini, I., Ambrosini, R., Imperio, S., Paiva, V.H., Gaibani, G., Saino, N. \& Cecere, J.G. 2014. The effect of moonlight on Scopoli's Shearwater Calonectris diomedea colony attendance patterns and Nocturnal Foraging: a test of the Foraging efficiency hypothesis. Ethology 120: 1-16.

Varpe, Ø., Tveraa, T. \& Folstad, I. 2004. State-dependent parental care in the Antarctic petrel: responses to manipulated chick age during early chick rearing. Oikos 106: 479-488.

Watanuki, Y. 1986. Moonlight avoidance behavior in Leach's Storm-Petrels as a defence against Slaty-backed Gulls. Auk 103: $14-22$. 